\title{
Networks of Revolutionary Workers
}

\author{
Socialist Red Women in Finland in 1918
}

\author{
Tiina Lintunen and Kimmo Elo
}

In January 1918, the socialist Reds in Finland resorted to force in their struggle for a social revolution, whereas the conservative Whites supported the government and wanted to expel the Russian troops still in the country. This chaotic situation became a civil war. ${ }^{1,2}$ Revolutionary ideas inspired thousands of women to support the Red Guard. These "Red women" worked both for the troops and as armed troops themselves. ${ }^{3}$ With the war ending in a victory for the Whites, the rebels (women as well as men) were tried for treason.

During the hearings, each defendant had to state why she had joined the Red Guard or otherwise supported the cause. The most common justifications given in their testimonies were economic - the good salary the Red Guard paid. Many also justified joining the Guard by saying, "Because others joined too", or "I was told to". ${ }^{4}$ Who were these "others", who had such an influence on these women? What were the overarching factors that brought these women together, and how were these women acquainted with each other?

1 This chapter was first published in the International Review of Social History 64, no. 2 (2019): 279-307. It is reproduced with permission of Cambridge University Press. The chapter contains various illustrations that are best viewed online and in full color. For the original article and supplementary online material, please visit https://doi.org/10.1017/ Soo20859019000336.

2 Over the years, there has been a great deal of controversy about the name and nature of the events that took place in Finland in 1918. After the war, the Whites used the term "War of Liberty"; the Reds talked about revolution and rebellion. Nowadays, most researchers use the neutral term "civil war".

3 The term "Red woman" can refer to a female soldier on the Red side, to a woman serving the Red side, to a Red agitator, or to a family member of a Red soldier. In our study, Red women are taken to mean women accused of treason and prosecuted in court. They came from all the groups mentioned above, the exception being female soldiers: there were no women soldiers in the district we studied.

4 Tiina Lintunen, Punaisten naisten tiet. Valtiorikosoikeuteen vuonna 1918 joutuneiden Porin seudun naisten toiminta sota-aikana, tuomiot ja myöhemmät elämänvaiheet (Turku, 2015), pp. $98 \mathrm{ff}$. 
The reasons the women gave were probably not always the real reasons: most women tried to minimize their sentences by understating their commitment and importance. It was rare for a woman to admit she had joined for political reasons. Surely, there were more women who shared these political views, since the majority of them were also members of the labour movement. ${ }^{5}$ The influence of others was also real. In previous studies, the example of family and co-workers proved to be an important factor in encouraging others to join the revolution. ${ }^{6}$ The situation was undoubtedly complex and the reasons why women joined the Guard were manifold. Ideology, money, and comrades were all contributory factors and will have differed from one individual to another. ${ }^{7}$

Our source material consists chiefly of documents produced by the authorities. Unfortunately this also means that the primary material available for this study included only fragmented and rare data on the social connections of these women. We reconstructed the prevailing social networks by treating the factors referred to above as social channels important for social interaction. Further, we assumed that geographical closeness (as implied by the same place of residence) strengthened social cohesion between women living in the same region. In order to model and analyse this complex set of relations, we decided to apply historical network analysis (HNA), a formal method developed to analyse and graphically present complex relationships.

Our hypothesis is that Red activity was based on organizations and everyday solidarity. The purpose of our chapter is therefore to analyse the networks of these Red women. What kind of connections were there? By exploring the networks, we are able to discover how revolutionary ideas were able to spread among workers. These networks were crucial not just before but also after the war, when the convicted women tried to survive in a society ruled by the Whites. The Reds were stigmatized as unfit citizens; support from other Reds was therefore of the utmost importance.

The Civil War is one of the most studied themes in Finnish history. It was also highly controversial - the terror during the conflict has aroused conflicting passions among researchers, and a great deal of controversy. Research into the collective memories of the period has also triggered heated debates. It has taken nearly a century to reach some sort of consensus that there is no one

$5 \quad$ Ibid., pp. 97-99.

6 See, for example, Tuomas Hoppu, Tampereen naiskaartit. Myytit ja todellisuus (Jyväskylä, 20o8), pp. 73-75, and Aimo Klemettilä, Tampereen punakaarti ja sen jäsenistö (Tampere, 1976), p. 241.

7 Lintunen, Punaisten naisten tiet, p. 101. 
monolithic truth about the war, but that several parallel interpretations are equally valid. ${ }^{8}$

The historiography of the research into the Finnish Civil War has gone through four waves. After the war, the official history was written by the victors. During this first wave, the war was described from the perspective of the Whites; the Reds were presented as the sole malefactors. Researchers referred to the war as a War of Liberation, Revolution, or Rebellion. In the 196os, the situation changed when greater consideration was given to the Red view. The most important studies of this second wave were by Jaakko Paavolainen on the Red and White terror and by Viljo Rasila on the social background of the war and its adversaries. For the first time, the actions of the Whites were analysed critically. ${ }^{9}$ One of the most important pioneers was Anthony F. Upton, who in 1980 wrote a comprehensive study of the Finnish revolution and Civil War. ${ }^{10}$ It was a sort of prologue to the third wave, which began in the 199os. This period was more neutral, and the term "civil war" gained ground among researchers. Also, a microhistorical approach emerged, with Risto Alapuro's and Heikki Ylikangas's path-breaking studies. ${ }^{11}$ Both of these turns - the focus on the Red point of view and their social background, and later the microhistorical approach - have been significant to our study.

During the present century, the historiographical emphasis has shifted towards new military history - the fourth wave, with research focusing on such phenomena as myths, emotions, violence, and everyday life. It was not until this phase that ordinary women and children and their experiences were included. ${ }^{12}$ Our study is interlinked with this field. By analysing women's networks, we are able to piece together at least some of their interactions and sphere of activity. As far as we know, ours is the first study of revolutionary women's networks in Finland, or indeed in any European country. Our

8 Tiina Kinnunen, "The Post-Cold War Memory Culture of the Civil War: Old-New Patterns and New Approaches", in Tuomas Tepora and Aapo Roselius (eds), The Finnish Civil War 1918: History, Memory, Legacy (Leiden, 2014), pp. 401-439, 401-403; Tuomas Tepora and Aapo Roselius, "Introduction: The Finnish Civil War, Revolution and Scholarship", in Tepora and Roselius, The Finnish Civil War, pp. 1-19, 8-15.

9 Jaakko Paavolainen, Poliittiset väkivaltaisuudet Suomessa 1918, 2 vols (Helsinki, 1966-1967); Viljo Rasila, Kansalaissodan sosiaalinen tausta (Helsinki, 1968).

10 Anthony F. Upton, The Finnish Revolution, 1917-1918 (Minneapolis, MN, 1980).

11 Risto Alapuro, Suomen synty paikallisena ilmiönä 1890-1933 (Helsinki, 1994); Heikki Ylikangas, Tie Tampereelle. Dokumentoitu kuvaus Tampereen antautumiseen johtaneista sotatapahtumista Suomen sisällissodassa 1918 (Porvoo, 1996). 
approach is microhistorical. We focus on a local community and its social layers in a political system in transition. We are interested in the common people and their lives.

This chapter contributes, too, to the field of the digital humanities ${ }^{13}$ and seeks to exemplify how quantified historical sources can be explored using digital methods and tools. We apply historical network analysis to analyse the significance and impact of regional, social networks and to improve our understanding of the structural factors affecting intra-group dynamics among the Red women who participated in the Finnish Civil War in 1918. Viljo Rasila used factor analysis in 1968 in his statistical study of the structures of Finland's political divisions in $1918 .^{14}$ We want to bring this study to the next level by studying the networks and closeness of the Reds.

Historical network analysis allows us to study the functions of multiple social background variables - here, we consider place of residence, kinship, and associations - in a much fuller way, and thus offers a promising tool for examining past communities at an aggregate level:

With SNA [social network analysis], we are only interested in individuals as part of a much bigger whole. In fact, one advantage to the technique is that SNA helps us view an entire community and figure out which individuals we should be truly interested in and which ones were perhaps less significant. When we study past relationships systematically as SNA allows, the method will prevent us from misunderstanding the function of an individual's relationships or exaggerating the distinctiveness of those relations. ${ }^{15}$

We chose these three variables because our hypothesis is that the connection of these women to the labour movement would be significant. According to previous studies, the political power of the working class was based on getting organized. So, the first choice was obvious. Place of residence was also

13 Since the whole discipline is subject to continuous, often controversial debate, there is no space in the present chapter for an exhaustive debate about the digital humanities. Useful contributions to this debate can be found in Anne Burdick et al. (eds), Digital_Humanities (Cambridge, MA, 2012), Frédéric Clavert and Serge Noiret (eds), L'histoire contemporaine à l'ère numérique / Contemporary History in the Digital Age (Brussels, 2013), and Matthew K. Gold and Lauren F. Klein (eds), Debates in the Digital Humanities 2016 (Minneapolis, MN, 2016).

14 Rasila, Kansalaissodan sosiaalinen tausta.

15 Robert M. Morrissey, "Archives of Connection", Historical Methods: A Journal of Quantitative and Interdisciplinary History, 48:2 (2015), pp. 67-79, 69-70. 
promising, since we knew that men's ties had been local. We wanted to see if this held true for women. Finally, kinship was chosen since we knew, after preliminary examination of the data, that there would be relatives, and previous research has shown the influence of family members to have been important. ${ }^{16}$

We are convinced that the power of digital methods such as historical network analysis lies in their ability to allow a distant reading of large material corpora. For example, social interaction patterns can be rather complex and hard to perceive without proper visualization. This is exactly what HNA is designed for: to model and visualize complex relationships in an attractive visual form. At the same time, however, we are fully aware that all network visualizations require a proper context-aware interpretation and that qualitative research is also needed. Further, the network data can be derived from documents containing only historical facts. A well-known problem is the static nature of graphical visualizations, often criticized for "freezing" the course of history. An often-used workaround is to "chunk" the network in temporal snapshots. For this chapter, we are interested in one point in time only - the beginning of the Finnish Civil War. Hence the problem of dynamic networks is not highly relevant here.

The first section of this chapter describes the historical context by briefly presenting the main developments in Finland in 1917 and the first few months of 1918, which resulted in the outbreak of the Finnish Civil War. In the second, we present our primary material and discuss our method: historical network analysis. The third section presents the main analysis and revolves around network visualizations. We conclude by summing up the most important results and their implications.

Background

The Civil War between the rebellious Reds and the conservative Whites broke out in January 1918. Its causes were multifarious and stemmed from both domestic and world politics. At the international level, the most important elements were, naturally, World War I and the collapse of the Russian Empire, the mother country of the Grand Duchy of Finland. After the downfall of the empire and the Bolshevik Revolution, Finland gained independence but was

16 Hoppu, Tampereen naiskaartit. Myytit ja todellisuus, pp. 73-75; Klemettilä, Tampereen punakaarti ja sen jäsenistö, p. 241. 
in such turmoil that it found itself embroiled in an agonizing and destructive civil war after only a few weeks of freedom. ${ }^{17}$

World War I had shaken the foundations of the society in Russia to which Finland belonged as an autonomous district. The two revolutions in 1917 also affected the western territories of the empire. With regard to the Finnish region, state power had already slipped out of Russian hands after the March Revolution. However, the political atmosphere was tense. The Russian provisional government was aware of Finnish separatist ideas and was keen to repress attempts to secure full sovereignty. Finns tried to achieve this sovereignty by making the Finnish Parliament the highest legislative body. The provisional government refused to accept this and dissolved parliament and ordered new elections. The Bolsheviks, on the other hand, supported Finnish separatist aspirations. They hoped that their revolutionary ideas would spread to Finland and thus further Bolshevik aims. ${ }^{18}$

During 1917, the domestic situation in Finland slowly evolved from minor disputes into ever-increasing violent conflicts. What circumstances led to this chaos? First, there was a serious shortage of food and work. Due to the chaos in Russia, Finland's trade to the east fell sharply and unemployment increased dramatically. There was also a severe lack of food because Finland was not selfsufficient and World War I interrupted grain imports from Russia, while in Finland itself the harvest was less abundant than usual. Price controls failed and the black market flourished. Workers were hungry and disappointed with the government and with producers. Riots and disorder became a part of everyday life. ${ }^{19}$

Second, politics failed. Socialists and bourgeoisie were unwilling to compromise amid the resurfacing of old, ideological, class-based conflicts. Universal suffrage in 1906 had not mended the deep class divisions and socialists and bourgeoisie were reluctant to share power, accusing each other of attempting a coup d'état. The socialists became frustrated when parliament was dissolved by the Russian provisional government in the summer of 1917 and they lost their majority after new elections in October 1918. If the political decision-making

17 Pertti Haapala and Marko Tikka, "Revolution, Civil War, and Terror in Finland in 1918", in Robert Gerwarth and John Horne (eds), War in Peace: Paramilitary Violence in Europe after the Great War (Oxford, 2012), pp. 72-84, 74-79.

18 William G. Rosenberg, "Paramilitary Violence in Russia's Civil Wars, 1918-1920", in Gerwarth and Horne, War in Peace, pp. 21-39, 22-24; Haapala and Tikka, "Revolution, Civil War, and Terror in Finland in 1918", pp. 74-75.

19 Pertti Haapala, "The Expected and Non-Expected Roots of Chaos: Preconditions", in Tepora and Roselius, The Finnish Civil War, pp. 42-50. 
processes had worked, the difficult economic situation might have been ameliorated. Things went from bad to worse, however, since political problems aggravated everyday concerns. ${ }^{20}$

Third, after the first Russian Revolution in March, there was no police force in Finland. Nor did it have an army of its own. There was no official paramilitary force to control restless crowds. In the summer and autumn of 1917, during the worker strikes and political unrest, local militia were founded in order to protect the political rights of strikers and also the rights and political agenda of the landed estate owners. These early militia were clearly class-based, especially in the countryside, but later their composition became more complex. ${ }^{21}$ Originally, the militia were regional and lacked general rules and cohesion. However, these coalitions were preliminary phases for the subsequent formation of the national Red and White guards, which both had c.10o,ooo soldiers. The Reds had 2,60o female soldiers, with a further 10,000 women as service troops. All of them were located in southern Finland. ${ }^{22}$

Finland gained its long-hoped-for independence in December 1917. It was not a time for celebration. Disagreements between socialists and non-socialists became more intense. Finally, despite efforts by more moderate party members, the radical socialists launched a revolution in January 1918. Inspired by the Russian Revolution, they were ready to seize the opportunity and carry out a coup d'état. However, they did not adopt the Bolshevik model. They believed in armed, but peaceful revolution. The Reds did not plan to make Finland a constituent part of Lenin's Russia but to create an independent state. This fundamental difference explains, at least partly, why people were so willing to join the revolution, which later became a civil war. ${ }^{23}$

$20 \quad$ Ibid., p. 40; Tuomas Hoppu, "Sisällissodan puhkeaminen", in Pertti Haapala and Tuomas Hoppu (eds), Sisällissodan pikkujättiläinen (Helsinki, 2009), pp. 92-111, 92f. Pertti Haapala, "Vuoden 1917 kriisi", in Haapala and Hoppu, Sisällissodan pikkujättiläinen, pp. 58-89, 80.

21 Most of the Red guardsmen were farmworkers or industrial workers. The Whites were a more heterogeneous group. Most of them were landowners, but there were also students, public servants, and middle management of industry and business. In between were the tenant farmers and handicraftsmen; they supported both sides. Marko Tikka, "Suomen sisällissodan tapahtumat", in Tuomas Tepora and Aapo Roselius (eds), Rikki revitty maa (Helsinki, 2018), pp. 82-110, 84; Alapuro, Suomen synty paikallisena ilmiönä 1890-1933, pp. $47-49$.

22 Risto Alapuro, State and Revolution in Finland (Berkeley, CA, 1988), pp. 145, 16o; Haapala, "The Expected and Non-Expected Roots of Chaos", pp. 45-47; Hoppu, "Sisällissodan puhkeaminen", pp. 92-111.

23 Hoppu, "Sisällissodan puhkeaminen", pp. 98-101; Rosenberg, "Paramilitary Violence in Russia’s Civil Wars", pp. 30-33; Haapala and Tikka, "Revolution, Civil War, and Terror in Finland in 1918", pp. $75 \mathrm{ff}$. 
As Jorma Kalela has pointed out, the historical events that occurred in Finland in 1918 should not be seen in isolation but as part of the series of proletarian revolts that took place in Europe from 1917 to 1920. However, the Finnish case had three characteristics that marked it out from revolts elsewhere in Europe. First, in Finland the proletariat was united. They split into communists and social democrats only after the revolution had been suppressed. Second, the revolutionaries managed to hold on to power for nearly three months. Third, in Finland the revolt took place earlier than in Central Europe, where the uprisings occurred only after World War I. ${ }^{24}$ The Finnish Civil War lasted for just over three months and ended in victory for the Whites. Though brief, the war was bloody and brutal. It left one per cent of Finland's population dead as a result of battles, terror, and famine in Pow camps. ${ }^{25}$

The Red revolution needed both soldiers and service workers. Women, too, were called up for duty. The Red administration was surprised that women were eager to take up arms. Approximately 2,60o armed themselves. They were generally unmarried and young - most of them were under the age of twentyone. Only some of them took part in battle; the rest acted as sentries. They did, however, play an important role in propaganda. Red newspapers used the fact that women were willing to risk their lives to put pressure on Red men to join in combat too. The Whites were appalled by the thought of women taking up arms, arguing that it was contrary to the social system and inappropriate for a woman to fight. ${ }^{26}$

For many years, the image of a Red woman has been dominated by those 2,60o armed females and the role they played in the history of the Finnish Civil War. In contrast, we know little about the unarmed Red women. There were approximately 10,000 women who undertook traditional duties, such as nursing and subsidiary tasks. ${ }^{27}$ They were older than the female soldiers; many of them were married and had children. They were seduced into joining not just by ideological considerations; good wages also played a role. The Reds had

24 Jorma Kalela, "Suomi ja eurooppalainen vallankumousvaihe", in Ville Pernaa and Mari K. Niemi (eds), Suomalaisen yhteiskunnan poliittinen historia (Helsinki, 2008), pp. 95-109, 103-105.

25 Marko Tikka, "Warfare and Terror in 1918", in Tepora and Roselius, The Finnish Civil War, p. 118.

26 Lintunen, Punaisten naisten tiet, pp. 36-38; Tuomas Hoppu, Sisällissodan naiskaartit. Suomalaisnaiset aseissa 1918 (Helsinki, 2017), pp. 71, 270.

27 There were more volunteers than the Guard could take. Some of the young women not hired to serve the army decided to form armed female companies. Despite the lack of general approval, 2,6oo women took up arms towards the end of the war. The women we study did not bear arms. 
occupied Helsinki in the first few days of the war and seized the Bank of Finland; this enabled them to offer generous salaries that doubled the incomes of recruits.

Most of these Red women were also members of the labour movement. Party members were consequently committed to the cause and wanted to help change the prevailing social system. ${ }^{28}$ As Hoppu and Klemettilä have already noted, money was therefore not the only reason for joining the Guard. ${ }^{29}$ Some of these women and girls undoubtedly did not understand the gravity of their actions in joining, nor were they aware of the serious consequences of this affiliation. For example, thirteen-year-old Karin Sandberg, who washed dishes in the Red Guard's canteen for two weeks, probably did not realise that this job would land her in court. ${ }^{30}$

\section{$2 \quad$ Materials and Methods}

To be able to examine the roots of an organization, we restrict our study to a particular region and community. ${ }^{31} \mathrm{~A}$ restricted area is a prerequisite, especially for network analysis. The subjects of our analysis are the women from the district of Pori, in western Finland (Map 4.1). ${ }^{32}$ This region is a fertile research subject, since it was situated near the front line and occupied by the Reds, who needed a large army service corps. Women were consequently also needed. Moreover, the labour movement was strong in this region, and workers were well unionized. Hence, the political atmosphere favoured radical change. Consequently, the second largest regional group to face trial in the political crimes courts after the war comprised women from this province.

Our data comprise 267 women. We included all women from the district of Pori accused of Red activity. After the war, these Red women ended up in court on charges of committing treason or assisting in treasonous activity. They had either worked in support roles, been agitators, or were Red refugees. These women form a heterogeneous group. Their ages vary from thirteen to

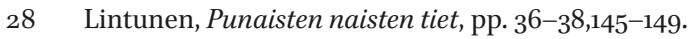

29 Hoppu, Tampereen naiskaartit. Myytitja todellisuus, pp. 73-75, and Klemettilä, Tampereen punakaarti ja sen jäsenistö, p. 241.

30 National Archive, Helsinki, Court for crimes against the State (VRO), doc. 143/270.

31 Alapuro, Suomen synty paikallisena ilmiönä 1890-1933, p. 14.

32 In her dissertation, Lintunen studied the background of these women, their role in the war, the punishment they received, and their subsequent lives. Lintunen, Punaisten naisten tiet. 


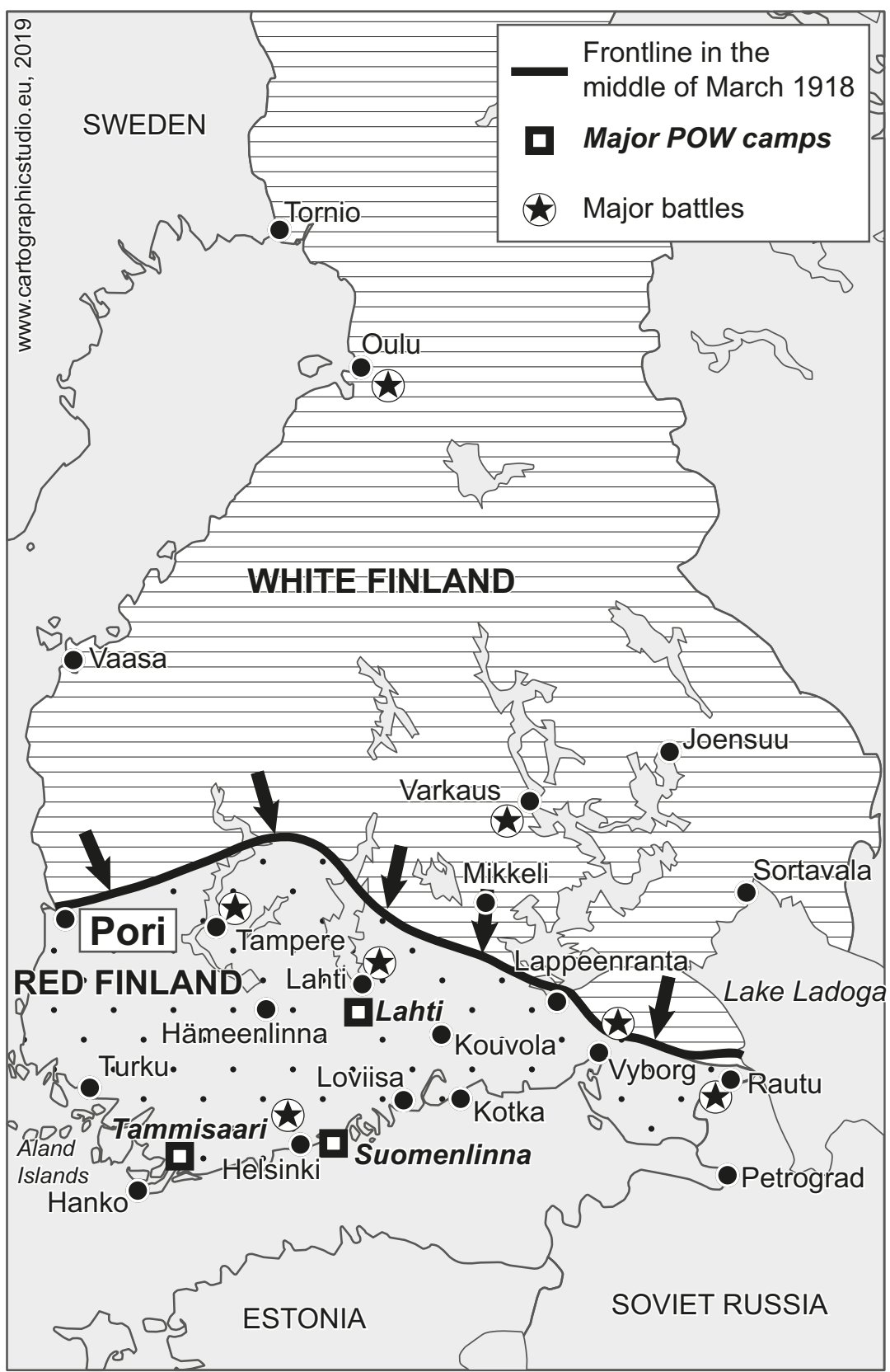

MAP 4.1 Southern Finland in 1918. Pori is located on the west coast near the front line. 
sixty-nine years, but most were in their twenties or thirties. Of the women, 53 per cent were unmarried, 37 per cent married, and 11 per cent were war widows. By profession, they were mainly factory workers, craftspeople, maids, or housewives; 69 per cent of them were members of the labour movement. ${ }^{33}$ We examine the connections among all these women. In addition, to tackle the microhistorical dimension, we closely examine the women from the Aronen family, as representative of the larger group of Red women, which comprised around 5,500 people tried in court after the Civil War. We refer to our research subjects by their own names since more than a century has passed and we aim to do justice to them by understanding their activity in the context of their era.

Our materials consist of documents from various archival sources. The trial documents in the National Archive contain ten to twenty pages of information on each defendant, including interrogation notes in which we can read their own stories and where they explain what they had done, why, and where. The statements given in the interrogations are documented on official forms; descriptions are normally brief. It should be noted that these statements were made under extreme duress and so should be interpreted cautiously. For example, many of the women lied about their union membership. There are also letters of recommendation from relatives and influential individuals, as well as abusive letters from foes. The files also contain an official certificate, a twopage statement from the local White authorities, and the court verdict. We use them to identify the women who were prosecuted for treason and to get an overall picture of them and their backgrounds. These documents were produced by the authorities. We also have a few interviews recorded with these women in the 196os. Unfortunately, there are no letters or diaries available and thus we have to content ourselves with this scarce material on the motives of these women.

The files of the local workers' associations and trade union branches in the Labour Archives reveal the political participation of these women. ${ }^{34}$ Furthermore, the local parish registers and municipal archives are used as a source of information about kinship and place of residence. Qualitative analysis does not help us identify the potential interrelationships between these women. We

\section{Ibid.}

34 These were two distinct organizations. The trade unions tried to improve the wages and working conditions of their members, and to reduce the number of working hours. Workers' associations aimed to improve working conditions nationally through legislation. They also strove to educate workers by organizing cultural and entertainment programmes. 
need network analysis to help us see the nexus of the social relationships and to identify the key women in the network.

\section{On Historical Network Analysis}

The structure and dynamics of relationships between the issues, events, and people underlying historical phenomena are of key interest in historical research. In recent years, many historians have shown a growing interest in applying digital or other formal methods to their empirical material in order to model and analyse patterns of social interaction underlying certain phenomena. One approach enjoying slowly growing popularity among historians is historical network research (HNR), a research paradigm stressing the importance of relationships among units (people, organizations, concepts, etc.) to explain historical phenomena. ${ }^{35}$

Network research itself dates back to the late nineteenth century, but it was the development of powerful personal computers and easy-to-use software allowing graphical presentations, i.e. visualizations of networks, that increased interest in network research among historians. Another important pioneering role was played by those digital or computational historians at the crossroads of computational science and historical research who showed how social network analysis can be exploited to address research questions relevant for historical research.

The main focus of HNR lies in analysing relational patterns such as social or institutional relations or interactions in a historical context. ${ }^{36}$ It has been applied to map, measure, model, and visualize relationships between different units in a network. In recent years, network visualizations have gained a central position in network research, for two reasons in particular. First, new, easy-to-use visualization software is available, making data visualization much easier. And second, network visualizations are an effective form of presenting complex relationships in an intuitive and quite easy-to-understand form. Additionally, different visualization layouts offer new possibilities for highlighting

35 See, for example, Peter Bearman et al., "Networks and History", Complexity, 8:1 (2002), pp. 61-71; Tom Brughmans, "Thinking Through Networks: A Review of Formal Network Methods in Archaeology", Journal of Archaeological Method and Theory, 20:4 (2013), pp. 623-662; Ruedi Epple, "Flucht und Unterstützung: Die 'Auskunftsstelle für Flüchtlinge' in Zürich und ihre Netzwerke",Journal of Historical Network Research, 1:1 (2017), pp. 106-145.

36 For a more detailed discussion about historical network research, see, for example, http:// historicalnetworkresearch.org/; last accessed 14 February 2019. 
network-related attributes or visualizing a node's relevance in regard to its close neighbourhood or the complete network. ${ }^{37}$

Historical network analysis as a spin-off of social network analysis is part of the Anglo-Saxon, quantitatively oriented development line of network research. Accordingly, HNR has its theoretical foundations in graph theory in mathematics, where a network is defined as a set of dots (nodes, vertices) and connecting lines (edges) between nodes. ${ }^{38}$ Both nodes and edges can be enriched by attaching both quantitative and qualitative attributes to them, and these attributes can be used in the analysis. The main purpose of using attributes, however, is to ensure that the formal network model, the network topology, provides valid, reliable, and appropriate information to answer the research question.

The analytical focus of network analysis lies in the network structure, consisting of nodes and edges, and is based on the assumption that both the units (nodes) selected for the analysis and the connections (edges) between these are significant when it comes to understanding and explaining the larger phenomenon the network is connected to. Consequently, the main purpose of using network analysis and visualization tools is to elucidate structural aspects from the research object neglected or left unidentified by other research methods or tools. Although the analogy is not perfect, strong similarities exist between network analysis and statistical analysis, especially at the level of the research process. The network metrics used to describe the central characteristics of a network's structure can be compared to coefficients produced by fitting a statistical model. From this perspective, both provide quantitative information about dependencies between variables in the data, thus improving our understanding of the phenomenon subject to analysis. ${ }^{39}$

The primary material used in this chapter was processed into quantified network data in three steps. First, we extracted all socially relevant information from the original historical documents. In addition to name and place of residence, we extracted information about membership of trade union branches and workers' associations, as well as about kinships. We justify this

37 For more on this, see, for example, John Scott, Social Network Analysis (London, 2013); Barbara Schultz-Jones, "Examining Information Behavior Through Social Networks: An Interdisciplinary Review", Journal of Documentation, 65:4 (2009), pp. 592-631; Marten Düring and Martin Stark, "Historical Network Analysis", Encyclopedia of Social Networks (London, 2011).

38 For a good introduction to graph theory, see Keijo Ruohonen, Graph Theory (Tampere, 2013). For good introductions to SNA, see, for example, Christina Prell, Social Network Analysis: History, Theory and Methodology (London, 2012); Scott, Social Network Analysis. Morrissey, "Archives of Connection". 
selection by the fact that societies and associations are among the most central forms of organizations with regard to collective action. ${ }^{40}$ This information was stored in an affiliation matrix, with each row representing one "Red woman" and each column representing a single variable. This table was imported to $\mathrm{R}$, a statistical package, ${ }^{41}$ for advanced analysis.

Second, we created the actual network data by connecting women who had been members of the same workers' association or the same trade union branch, and who had lived in the same residence. We also added connections based on kinship. In the third step, we imported the network data to Visone, an open-source software program for network analysis and visualizations. Visone offers an extensive set of analytical tools and innovative network visualization integrated into an intuitive, easy-to-use user interface. ${ }^{42}$

\section{Social Networks of the "Red Women"}

We have split our analysis into three main parts, each analysing the same network data from a specific perspective. The methodological aim is to exemplify and evidence how historical social network analysis can be exploited to analyse the historical social reality reconstructed and represented through social networks. Each sub-analysis starts with a specific network visualization seeking to highlight analytically interesting and relevant aspects from the social networks of selected Red women residing permanently in the Pori region.

All networks visualized and analysed in this chapter are one-mode networks, where two women are connected if they are members of the same workers' association, the same local trade union branch, or if they share the same place of residence. Since the network data is created by projecting a twomode network - for instance, a person to trade union branch network - onto a one-mode social network - for instance, onto a person-to-person network where connections are based on shared trade union branch membership - all nodes sharing the same affiliation form a fully connected clique. Such a projection is also needed as we want to calculate some network measures and most of these are defined for one-mode networks only. ${ }^{43} \mathrm{We}$ are aware of the issues

40 Alapuro, Suomen synty paikallisena ilmiönä 189o-1933, p. 14.

41 www.r-project.org; last accessed 5 March 2019.

42 For further details, see http://visone.info/html/about.html; last accessed 14 March 2018.

43 Stephen P. Borgatti and Martin G. Everett, "Network Analysis of 2-Mode Data", Social Networks, 19:3 (1997), pp. 243-269. 
constraining the application of certain network measures to a projected onemode network ${ }^{44}$ and systematically avoid using these. Further, as regards the overall objectives of this chapter, these technical and theoretical issues are less relevant and do not outweigh the benefits of using projected one-mode network data in order to explore social interaction patterns. Another advantage is that the reader can visually explore - by focusing on the link colours - what kind of connections exist between the women.

Map 4.2 illustrates the geographical closeness of the city of Pori. As we can see, Pori's city centre was very compact and the distances between the city's sections very short. However, the Pori region was geographically rather large and included districts far from the centre. A good example is the district of Reposaari, an island located twenty-five kilometres northwest of the centre. ${ }^{45}$ The labour movement was very active in Reposaari. Of the women we studied who came from there, eighty-two per cent were organized. ${ }^{46}$ Our study also includes the rural communes in Pori and Ulvila, both located around the city of Pori. Those parishes were geographically fragmented and comprised several small villages across a quite large geographic area. At the beginning of the twentieth century, it was difficult for the poor to travel far - the chief means of transport was by foot. Thus, geographical mobility was low and communication over longer distances often depended on newspapers and visits from political activists. ${ }^{47}$

We start our exploratory analysis with Figure 4.1, which presents the social network of the 267 women based on their membership of workers' associations and trade union branches. Each node in the network represents one woman. The connections (links) visualized in green indicate that the two women were members of the same workers' association; the connections visualized in red

44 Tore Opsahl and Pietro Panzarasa, "Clustering in Weighted Networks", Social Networks, 31:2 (2009), pp. 155-163.

45 In summer there was a steamboat connection linking Reposaari to the city of Pori.

46 National Archive, Court for crimes against the State (VRO and vrYo).

47 The city of Pori had 17,603 inhabitants, the rural commune of Pori 7,685 , and Ulvila 8,339 . Suomen tilastollinen vuosikirja 1919 (Helsinki, 1920), pp. 12, 14. The three parish were interlinked since some Ulvila villages were considered suburbs of the city of Pori. Quite a few people from the nearest Ulvila villages and the rural commune of Pori worked in the city's factories. Jussi Koivuniemi, Joen rytmissä. Porin kaupungin historia 1940-200o (Pori, 2004), p. 20. 


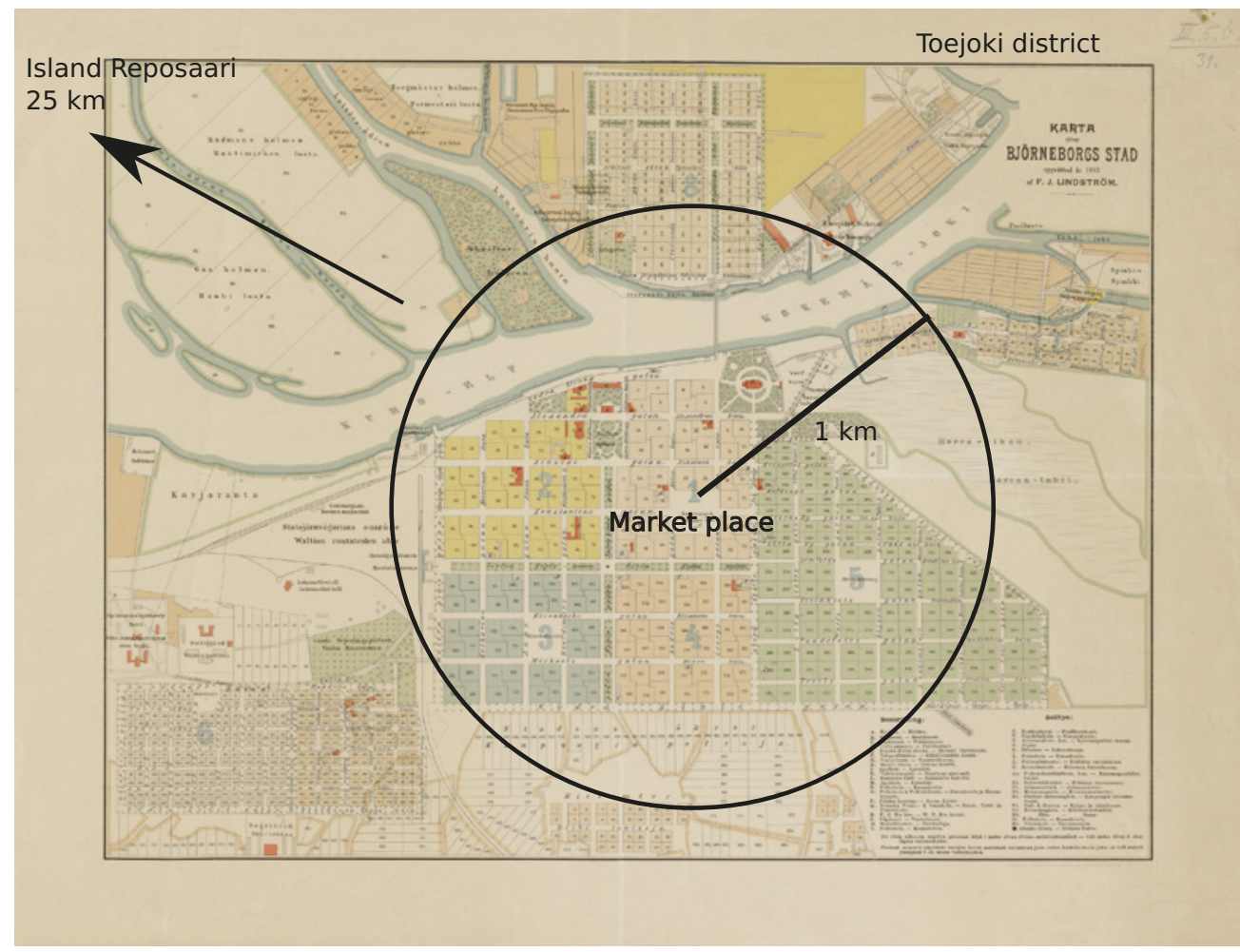

MAP 4.2 Map of the city of Pori

NATIONAL LIBRARY, DORIA, COLLECTION OF FINNISH MAPS, PORI 1895

represent membership of the same trade union branch. Although all links of the same main type (workers' association or labour union branch) are visualized in the same colour, heterogeneity within the same main type has been maintained. Hence, each individual workers' association (green links) is visualized as its own sub-network and connects only those women who were members of this specific association. ${ }^{48}$ The visualization is based on the "stress minimization" layout, a variant of force-directed layouts widely used in social network analysis. As the name suggests, the graph is treated as a spring system and the algorithm looks for a stable, "aesthetically pleasing" configuration

48 We have included all workers' associations and trade union branches of which the women were members. There were other trade union branches and workers' associations, but their female members did not end up in court accused of being Red. 

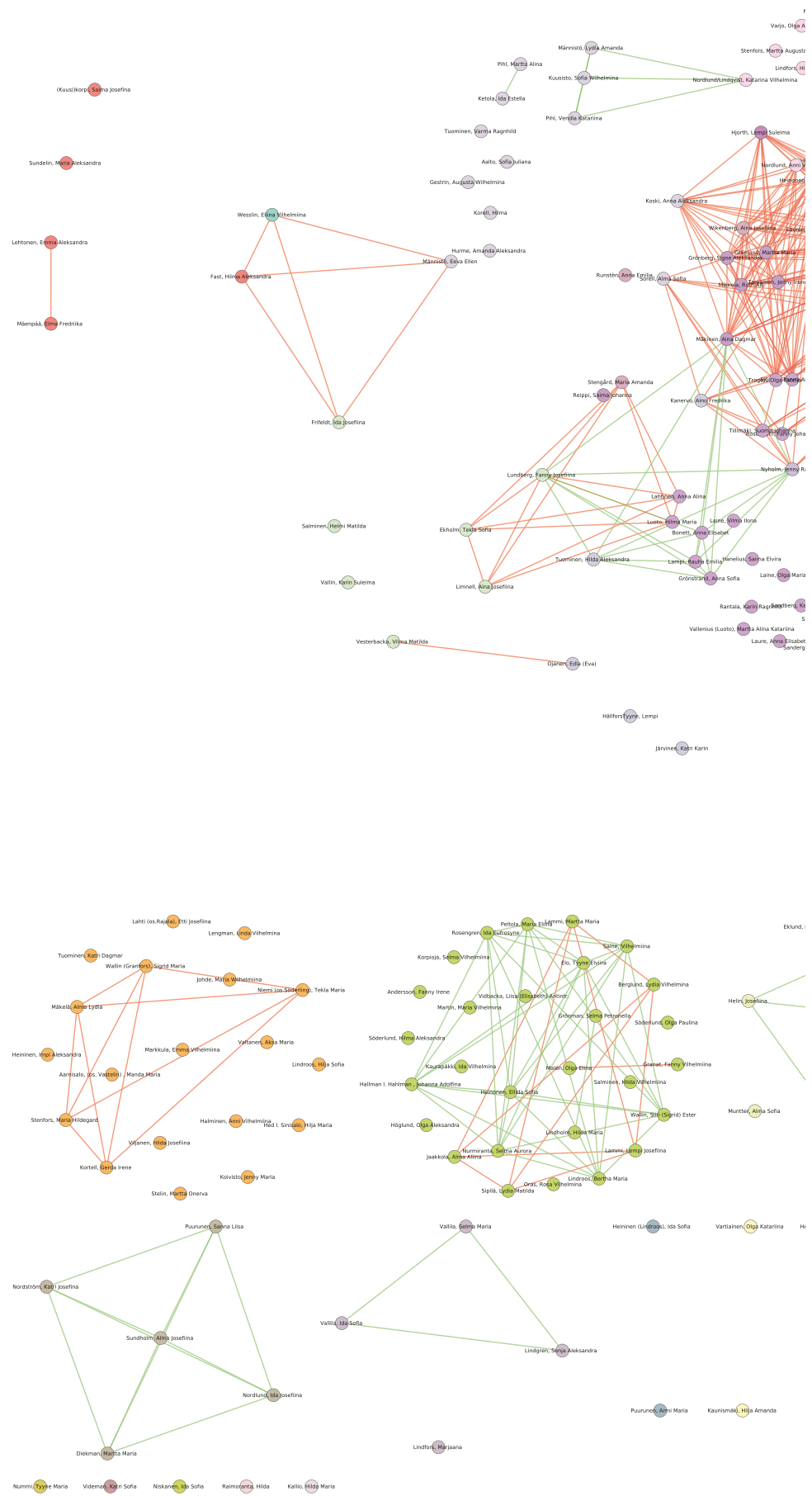

FIGURE 4.1 Social network based on membership of trade union branches and workers' associations FOR FULL-COLOR VERSION, SEE HTTPS://DOI.ORG/10/1017/S0020859019000336 
tan Sorfa

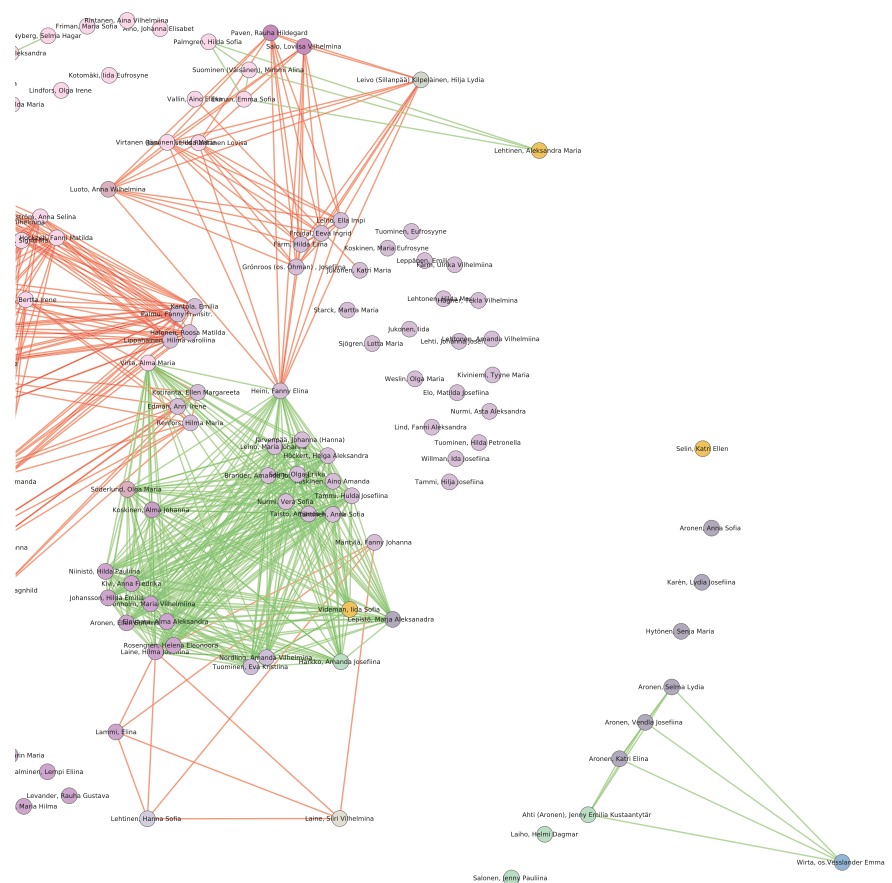

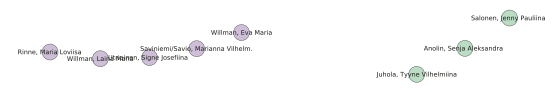

Lastongerom Mirs
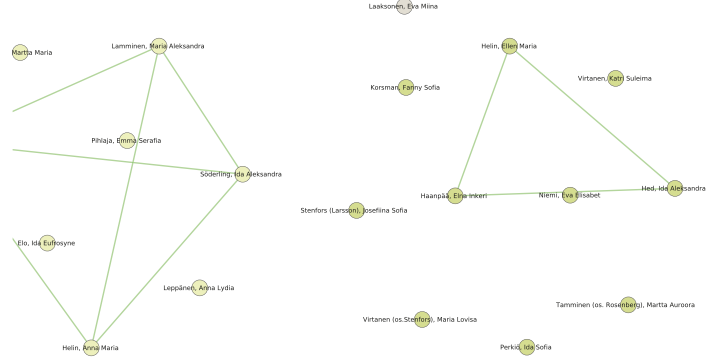

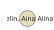

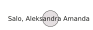

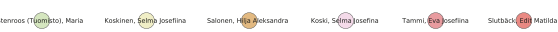

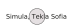

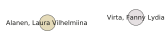


displaying "as much symmetry as possible".49 The resulting graph is designed so that nodes having more mutual connections are visible as clusters/cliques.

Figure 4.1 evidences the important role of workers' associations and trade union branches as the most remarkable factors that linked these women. In fact, sixty-nine per cent of them were members of the labour movement. Thus, the majority of these women were politically active and so would also have had political motives for supporting the revolution. It was quite natural for members of the Red Guard to also have been active members of the workers' movement. In addition, at the beginning of the war, the Reds wanted to recruit women of a mature age, not young girls, to serve the forces. The women chosen had previously proved their loyalty to the cause, and the generous salary was seen as a kind of reward for their efforts on behalf of the labour movement. They also encouraged one another. For example, Helena Rosengrén told her interrogators that Amanda Nordling fetched her from home and asked her to work with her in the Red kitchen. Both were members of the same workers' association. ${ }^{50}$ Likewise, Hilda Tuominen said that her acquaintance Johanna Järvenpää had urged her to join the Red Cross of the Red Guard with her. They were both seamstresses and members of the workers' association. The two of them were hired to sew bandages. ${ }^{51}$

Geographical Closeness

The social networks visualized in Figure 4.1 suggest the majority of these women were politically active, but there are a significant number of "isolates", i.e. women who joined neither a trade union, nor a workers' association. That a majority of them decided to join the Guard raises the question how these women acquired political information possibly relevant to that decision.

Since our primary sources are rather limited, even non-existent as regards daily interaction, for a plausible answer to this question we must rely on secondary sources, as well as on theoretical research on social proximity and closeness. Regarding the former, one should bear in mind that, apart from these active members of the labour movement, many others sympathized with the social democrats, read their newspapers, and participated in their

49 Stephen G. Kobourov, "Spring Embedders and Force Directed Graph Drawing Algorithms", eprint arXiv:1201.3011, 2012, available online at https://arxiv.org/pdf/1201.3011.pdf; last accessed 20 September 2018.

50 National Archive, Court for crimes against the State (VRO), doc. 141/384.

51 Ibid., doc. 141/610. 
gatherings in the People's Halls even though they did not pay the membership fee, ${ }^{52}$ making them "unconnected isolates" in our visualization. According to the sociologist Risto Alapuro, these non-members belonged to the same social networks as the active members of the workers' association, and the mutual meeting places of the networks were usually the local People's Halls. ${ }^{53}$ Moreover, the historian Kari Teräs, who has studied the commitment of Finnish workers to trade unions, found that people on the inner and outer levels of the union organization were connected to each other in their everyday life and in various collective activities. Thus, the trade unions' sphere of influence was much wider than their membership. Those who participated in the activities organized by the union often shared the same worldview and values of the actual members. ${ }^{54}$ We can presume that these individuals on the fringes of the workers' movement would be aware of any revolutionary plans. Many of them adopted these ideas and supported the Red Guard.

In several cases, membership of a local trade union branch shows that many of the women in this study worked in the same locations. For example, the members of the cotton mill workers union or Pihlava's sawmill union worked in the same premises and met each other daily. ${ }^{55}$ Thus, they probably talked to one another about joining the Guard and encouraged each other to do so. For example, Fanni Sjöman claimed that Fanni Hockzell had persuaded her to join the Guard. They both worked in the cotton mill. ${ }^{56}$ Previous research supports this notion: persuasion, pressure, and inspiration at the workplace were important factors when workers were considering whether to join the Guard. For example, sixty-three per cent of members of the armed female company in Valkeakoski worked at the same paper mill. In Hyvinkää, eighty per cent of those alleged to be Red women had worked together at the same woollen mill and most were union members. Men's union branches, for example carpenters and shoemakers in Helsinki, also formed their own companies. Usually, however, it was the workers' associations that provided local troops. ${ }^{57}$

\footnotetext{
52 Lintunen, Punaisten naisten tiet, pp. 75-77.

53 Alapuro, Suomen synty paikallisena ilmiönä 1890-1933, pp. 102ff.

54 Kari Teräs, Arjessa ja liikkeessä. Verkostonäkökulma modernisoituviin työelämän suhteisiin 1880-1920 (Helsinki, 2001), p. 312. See also Leena Enbom, Työväentalolle vai seurahuoneelle? - Työväen vapaa-ajantoiminta, politiikka ja vastarinta 1920- ja 1930-lukujen tehdasyhdyskunnassa (Helsinki, 2014), p. 94.

55 National Archive, Court for crimes against the State (VRO and vRYo).

56 Ibid., doc. 143/279.

57 Varpu Anttonen, "Valkeakosken naiskaarti Suomen sisällissodassa 1918" (Master's thesis, University of Tampere, 2009), pp. 33, 40; Essi Ylitalo, “'Innokas punikki'. Hyvinkään punakaartilaisnaiset sisällissodan jälkiselvittelyissä 1918” (Master's thesis, University
} 
All this points to the importance of place and geography. We should keep in mind that in the late 1910s, Finland was a pre-industrial, agricultural society and that most people lived and worked within a small geographical area. This also holds true for the Pori region. Further, several empirical studies have tackled the question of the impact of geography on social networks, resulting in a rather promising theoretical consideration of how geographical proximity supports social closeness and interactions. ${ }^{58}$ For example, in his seminal study on kin and neighbours, Smith raises the role of residential propinquity by concluding that the "family systems may well have been 'functionally extended' both in horizontal and vertical directions" ${ }^{59}$ Smith continues - in accordance with our assumption that political ideas and information were disseminated among close neighbours - that neighbours "who in many cases were more important than kin, played a significant role through the giving of pledging support and aid in agricultural tasks".60

To test whether the idea of "functional extension" through neighbourliness is supported in our case, we enriched our network by adding geographically based connections - i.e. the place of residence information available in our data - to our initial network. We followed a simple procedure: if two women lived in the same location, a geographical connection was deemed to have existed between them.

The geographically extended social network of the Red women is visualized in Figure 4.2, where the geographical links are coloured blue (all other visual effects as in Figure 4.1). Due to the projected one-mode data, the places of residence determine the network representation (blue ties). Especially when Figure 4.2 is compared with Figure 4.1, this helps us to understand how the membership of different organizations actually connected different geographical locations. But also, how the geographical distance (Map 4.2) disconnected certain actors from the core network revolving around the centre of Pori. What is evident is that the geographical neighbourliness explains approximately half of the connections between two distinct women. In other words, the social interaction structure established through shared memberships in a workers' association or a trade union branch was functionally extended though

of Helsinki, 2011), pp. 17-18, 84; Marja-Leena Salkola, Työväenkaartien synty ja kehitys punakaarteiksi 2 (Helsinki, 1985), pp. 68ff, 422.

$5^{8}$ Ling Yin and Shih-Lung Shaw, "Exploring Space-Time Paths in Physical and Social Closeness Spaces: A Space-Time GIS Approach", International Journal of Geographical Information Science, 29:5 (2015), pp. 742-761.

59 R.M. Smith, "Kin and Neighbors in a Thirteenth-Century Suffolk Community", Journal of Family History, 4:3 (1979), pp. 219-256, 247.

60

Ibid., p. 247 . 
neighbourliness. Theoretically - but based, too, on the empirical facts about the role of the local People's Halls and shared activities - all the women were able to join a workers' association or a trade union branch. But they decided not to do so, making the organizational non-tie between women in the outer and inner layers just as important as a tie. ${ }^{61}$

The geographically expanded social network comprises twenty-two components, or separate sub-networks, that have no shared connections with the other components. If the original network based on associational connections had 124 isolated women, the second network has only eleven non-connected nodes (women). These nodes consist of housewives, maids, or women who were independent craftswomen. A majority of these isolates resided rather far from the industrial centres in the countryside in rural communes or in smaller villages in the Ulvila region. ${ }^{62}$ However, these women constitute only about four percent of our total sample, thus forming a tiny minority. The biggest subnetwork - in network terminology, the giant component - can be easily identified in the topmost part of the graph. This giant component consists of 172 women (sixty-four per cent of all the women) and has about 2,50o edges. The dense area in the centre of the giant component connects women who lived in the IV, V, and Toejoki districts of the cities of Pori and Ulvila. These areas are marked in Map 4.2. As Map 4.2 shows, those districts were all within walking distance of one another.

The "functional extension" thesis referred to above seems to apply to our network as well, especially when we focus on the connections between those women who lived in different districts but were members of the same organizations. The workers' association and trade union branch networks were rather small, but, as previous research has evidenced, smaller networks tend to produce a higher level of emotional closeness typical of families or/and kin relations. ${ }^{63}$ In our case, the organizational connections among the geographical districts were fewer than those within the districts, resulting in what Ronald S. Burt defines as "a network of strongly interconnected elements $[. .$.$] in which$ people can broker connections between otherwise disconnected segments", ${ }^{64}$ thus creating competitive advantage with respect to information access for

61 Morrissey, “Archives of Connection", p. 72.

62 National Archive, Court for crimes against the State (vro and vrYo).

63 Sam G.B. Roberts and Robin I.M. Dunbar, "Communication in Social Networks: Effects of Kinship, Network Size, and Emotional Closeness", Personal Relationships, 18 (2011), pp. 439-452.

64 Ronald S. Burt, "Structural Holes versus Network Closure as Social Capital", in Nan Lin, Karen S. Cook, and Ronald S. Burt (eds), Social Capital: Theory and Research (Berlin, 2001), pp. $31-56$. 

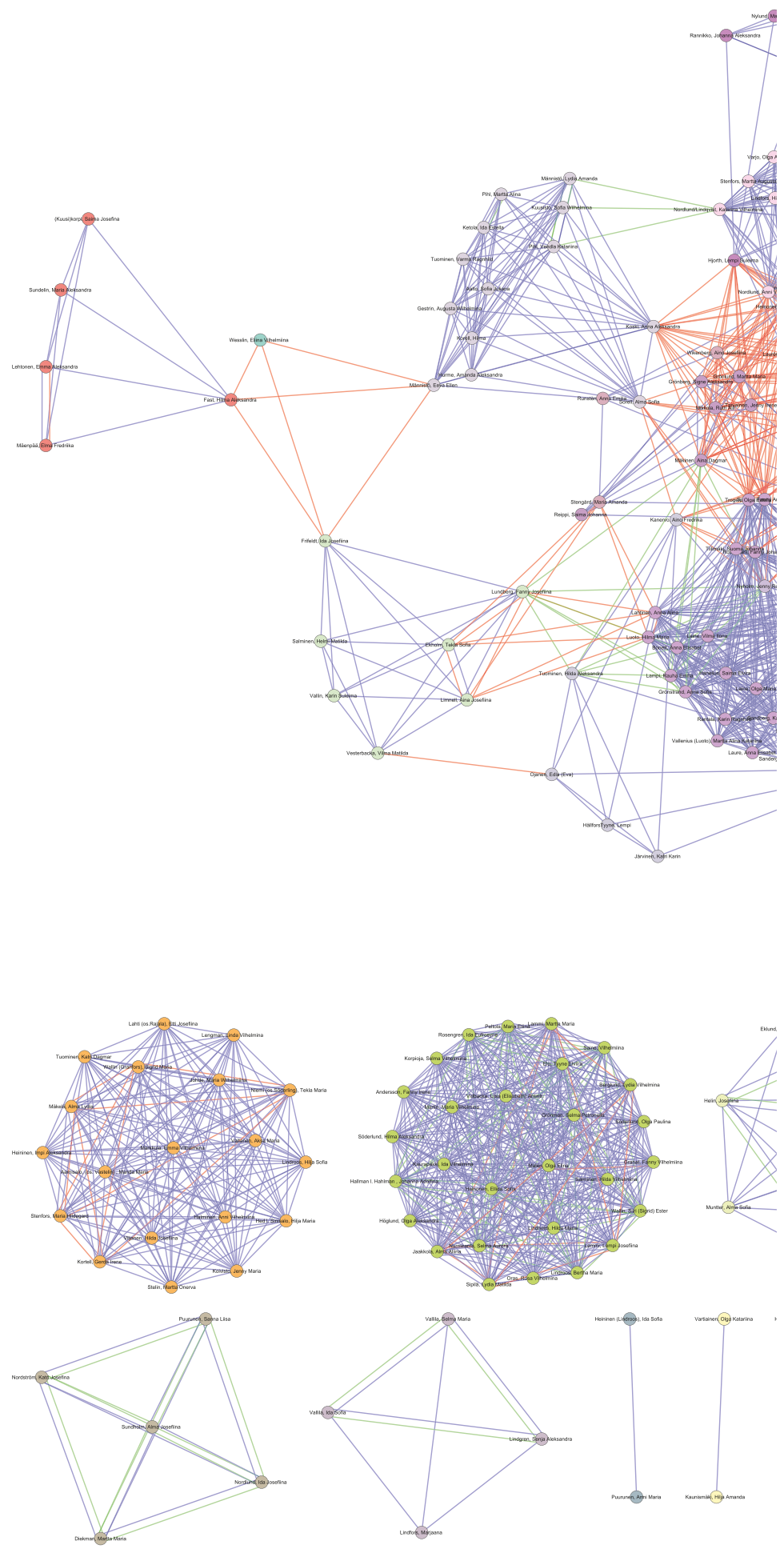

FIGURE 4.2 The complete network of Red women in the region of Pori in western Finland FOR FULL-COLOR VERSION, SEE HTTPS://DOI.ORG/10.1017/S0020855919000336 98904440395 


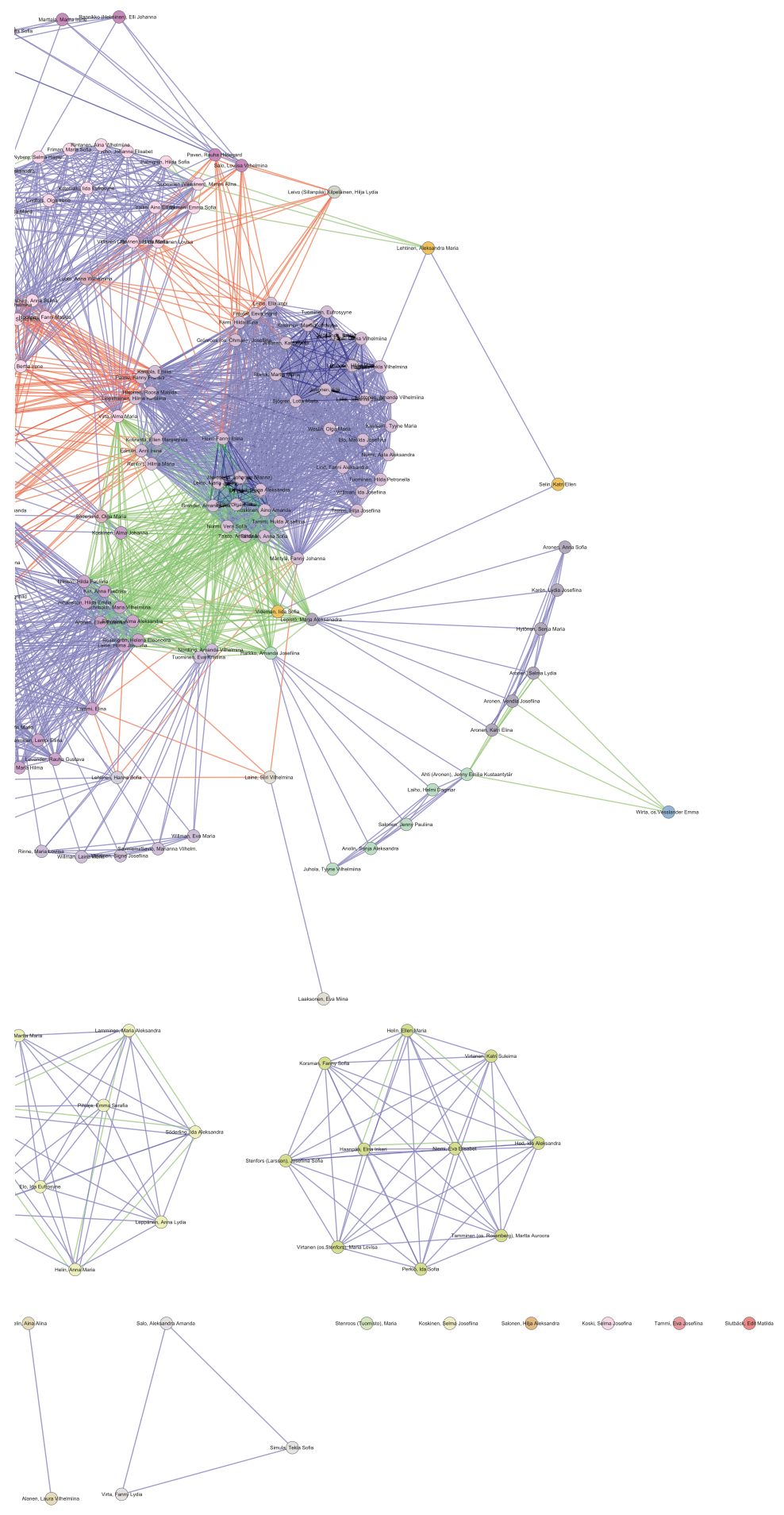

Tiina Lintunen and Kimmo Elo - 9789004440395

Downloaded from Brill.com@4/26/2023 12:26:14PM 
those women having organizational connections to women in other districts. ${ }^{65}$ This is exactly what we observe when focusing on the role of membership of an organization: these women could transfer valuable information; they could also gatekeep it from one group to another. At the same time, however, they were dependent on their neighbours within their district, because their success in reaching non-members in a certain district depended heavily on the neighbourhood's ability to act as a "functional extension" for political communication. This also helps explain why not all women living in geographically close districts joined a workers' association or trade union branch: in a situation where the neighbourhood truly acted as a functional extension for the organizations, there was no need to join an organization in order to maintain ideological closeness. ${ }^{66}$

The following case illuminates our argument. During the Civil War, Aino Helin, an eighteen-year-old girl, was talking on the street with two of her friends from the same village when a man from the Guard struck up a conversation with them. He asked if they would be willing to join the Guard's First Aid. Aino was a member of a social democratic youth organization and immediately felt enthusiastic. The other girls wanted to follow as well. They hoped to join the Guard together and work together, as friends. It felt like an adventure and the three girls did not need to think long, Aino Helin later explained in an interview. $^{67}$

There is a special form of social connection relevant for our case as well: kinship. Although a vast majority of historical network studies deal with social relations among families, clans, or other forms of kin relations, ${ }^{68}$ the kin itself has been studied as an end in itself: "Charting 'who lived with whom' became the answer to the question of how people related to each other in the past", resulting in a rather scarce number of empirical studies on kinship and

65 Ibid.

66 See also Roberts and Dunbar, "Communication in Social Networks", p. 440.

67 Interview with Aino Helin, Uusi Aika, 27 May 1978.

68 See, for example, Barry Wellman and Charles Wetherell, "Social Network Analysis of Historical Communities: Some Questions from the Present for the Past", The History of the Family, 1:1 (1996), pp. 97-121; Charles Wetherell, "Historical Social Network Analysis", International Review of Social History, 43:S6 (1998), pp. 125-144. 
social relations. ${ }^{69}$ Generally speaking, kinship relations enjoy a special status in social network analysis since they seem to be less prone to decay, ${ }^{70}$ foster emotional closeness, ${ }^{71}$ and are important for maintaining identity. ${ }^{72}$ Also in our data, kin relations seem to be important: of our total of 267 women, fifty were related to one another. In most cases the degree of relationship was close; there were mothers and daughters, sisters and in-laws. It was the rule rather than the exception that the men of these families also participated in the Red Guard, whether as a husband, a father, a brother, or a son. The families often shared the same ideological worldview and even encouraged one another to join. For example, seventeen-year-old Ida Perkiö said her brother had advised her to join the Guard. Anna Kivi explained that her own husband, who worked for the Guard, had asked her to join since they did not have children and she was not employed. ${ }^{73}$

We selected the Aronen family (Figure 4.3) for a closer analysis since they played an exceptionally remarkable role in the district. Six women from this single family were prosecuted. They were suspected of treason not only due to their own actions but also due to the important positions of the men in the family. For example, Nestori Aronen, Anna Aronen's son and the husband of Selma Aronen, was the right hand of the Red's chief procurator and worked in the headquarters of the Red administration. But these women were not simple bystanders. For example, Selma had been a key figure in the pre-war labour movement. She was the chairwoman of the women's section of the local workers' association and thus had influence and access to information. ${ }^{74}$ Anna, in turn, lived in a house that also served as the headquarters first of the workers' association and later of the local Red Guard. She was able to acquire information and pass that on to her acquaintances. ${ }^{75}$

All the husbands of these women were members of the Red Guard. The Aronen brothers were leaders of the local Guard, and after the war the entire family were branded as rebels and charged with treason. None of the six women had joined the Red Guard, but they had supported it. They were accused

69 Hilde Bras and Theo van Tilburg, "Kinship and Social Networks: A Regional Analysis of Sibling Relations in Twentieth-Century Netherlands", Journal of Family History, 32:3 (2007), pp. 296-322, 297, 300.

70 Ronald S. Burt, "Decay Functions", Social Networks, 22 (2000), pp. 1-28.

71 Roberts and Dunbar, "Communication in Social Networks", p. 446.

72 Ralph Piddington, "The Kinship Network among French Canadians", International Journal of Comparative Sociology, 6 (1965), pp. 145-165.

73 National Archive, Court for crimes against the State (VRo), doc. 141/73 and 47/12O.

74 National Archive, Court for crimes against the State (VRYO), doc. 20898.

75 Ibid., doc. 20897 . 


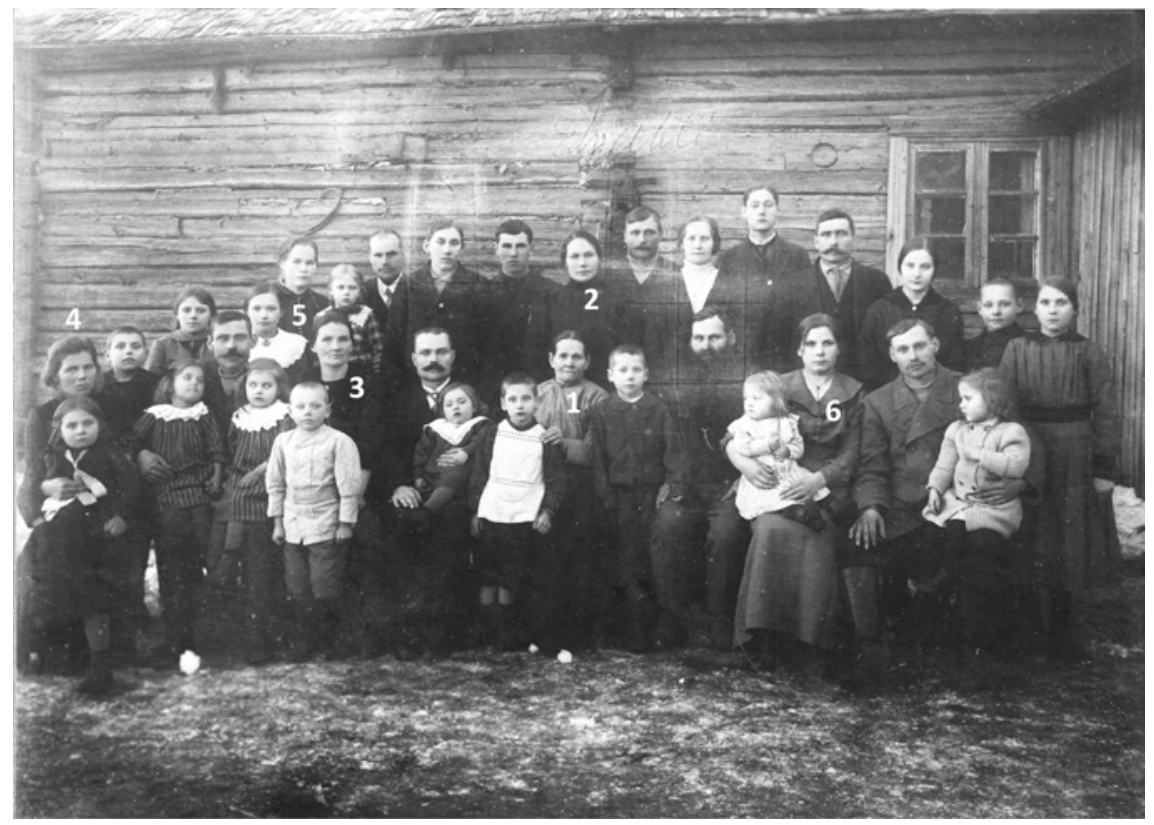

FIGURE 4.3 The Aronen family. A photograph of the Aronen family, taken in 1917. The women in our research are indicated as follows: 1. Anna, the matriarch (69); 2. Jenny, daughter (33); 3. Selma, daughter-in-law (39); 4. Vendla Josefiina, daughterin-law (36); 5. Ellen, daughter-in-law (23); 6. Katri, daughter-in-law (21). Juha Kuoppasalmi, Nestori Aronen - tunteita ja taisteluita (Helsinki, 2018), p. 36. USED BY PERMISSION. PHOTOGRAPH EDITED BY TIINA LINTUNEN

of agitating for rebellion and of hiding guns and stolen property. Only the two youngest women, Katri and Ellen, were acquitted on all charges. The other four were sentenced to penal servitude, though they were all released within a year in general amnesties.

Figure 4.4 focuses on the social network of the Aronen family by dimming all nodes and edges other than those around its members, thus highlighting the central position of the Aronen clan in our network. The Aronen family are visualized in red, the members of their ego networks are marked in blue, and their neighbours are visualized in cyan. In total this "Aronen network" was at most only two steps removed from 143 (54 per cent) of the 267 women in our sample and covered - as the visualization evidences the core geographical area located in the central districts of Pori (see also Map 4.2). 


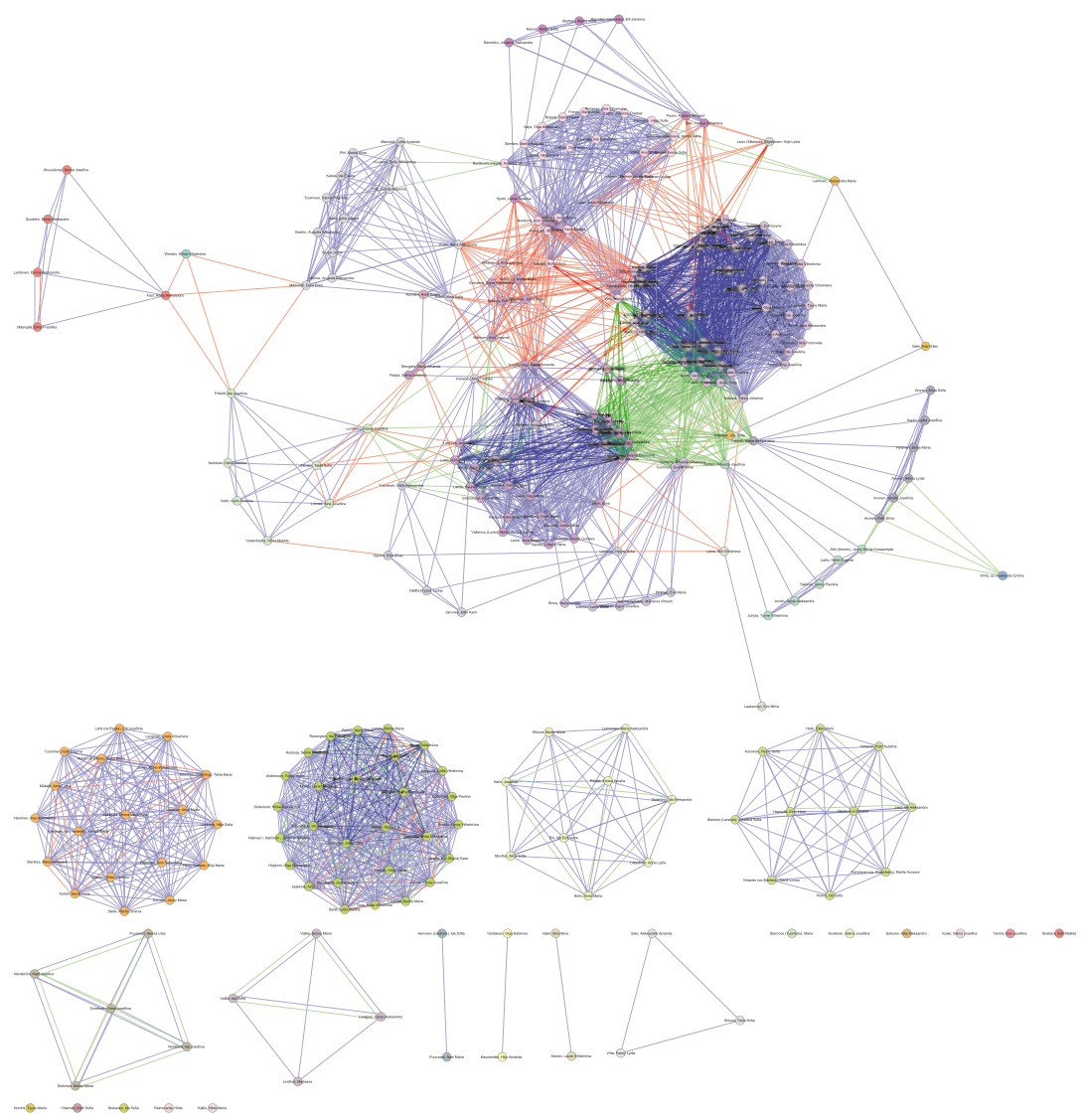

FIGURE 4.4 The social connectivity of the members of the Aronen family FOR FULL-COLOR VERSION, SEE HTTPS://DOI.ORG/10.1017/\$0020859019000336

The central position of the members of the Aronen family is supported also by network measures. We use the closeness centrality measure to analyse a woman's structural position in the network. Closeness centrality measures the mean distance from a node to other nodes in the network, thus providing information on how easily a node can reach other nodes in the network, or, in other words, how close a node is to all other nodes in the network. ${ }^{76}$ Normally, closeness centrality is standardized on a scale from $\mathrm{o}$ to 1 , where $\mathrm{o}$ indicates an isolated node and $1 \mathrm{a}$

76 Scott, Social Network Analysis, pp. 84ff. See also Ulrik Brandes, Sven Kosub, and Bobo Nick, “Was messen Zentralitätsindizes?", in Marina Hennig and Christian Stegbauer (eds), Die Integration von Theorie und Methode in der Netzwerkforschung (Wiesbaden, 2012), pp. $33-5^{2}$. 
node having a direct connection to all other nodes in the network. By definition, nodes with a higher closeness centrality might have better access to information at other nodes or more direct influence on other nodes.

Closeness centrality measures of the six members of the Aronen family support their central position in the network of the Red women. Ellen Aronen, whose ego network covers Pori's central districts with forty-six connections, has a closeness centrality of 0.340 , the highest in the family. Jenny, Selma, Vendla, and Katri Aronen each have a closeness centrality of 0.215 , followed by Anna Aronen with 0.212 . An interesting observation is that all women with the highest closeness centrality measures (from 0.355 to 0.343 ) are Ellen Aronen's ego connections. Hence, Ellen Aronen not only had better access to information and more direct influence on other women, she could also mobilize women in her direct neighbourhood in order to gain even more influence.

As these results evidence, the Aronen family were able to reach practically all the members of the most central network in the Pori region. This confirms a central insight from network analysis, which is that most networks tend to have certain key individuals - in our case the Aronen family - with multiple connections. ${ }^{77}$ At the same time, the Aronen network confirms the importance of weak links: the kinship network of the Aronen family was rather small, but it had access to a huge network of associates, enabling the Aronens to reach women in most central associations and districts.

As can be seen, these women were politically active and had wide connections through the labour movement. This was important since their husbands were in leading positions and had knowledge of the revolution's progress. Thus, these women could pass on information through their networks to other women in the district. Kinship with the Aronens proved to be a dangerous connection after the war, as was highlighted in the court statements. For instance, Anna was described as a mother "who has raised sons who have stirred up the whole world 'to rebellion'." 78 In Jenny's papers it was claimed that "she is one of the socialist villains of Aronen".79 The entire family were labelled Red rebels. This was common after the Finnish Civil War; the acts of one family member could define the reputation of the entire family in the eyes of society. In addition, membership of a trade union or socialist association was considered an aggravating factor after the war since the Social Democratic Party

\footnotetext{
77 Morrissey, "Archives of Connection", p. 77.

78 National Archive, Court for crimes against the State (VRYO), doc. 20897.

79 Ibid., doc. 7019 .
} 
was regarded as a scapegoat for the rebellion. Thus, the Aronen women had both their political background and their kinship with revolutionary leaders on their crime sheet.

The experiences of 1918 also united these women more strongly. Both Anna and Jenny lost their husbands in the aftermath of the war. The men died in Pow camps. Jenny moved back home to live with her mother. Selma, Vendla, and Katri also needed support since their husbands were given long sentences and were not released until the 1920 . They all had young children; Vendla gave birth to a baby in the autumn of $1918 .{ }^{80}$ In a crisis like this, support networks were of the utmost importance. The support of people with similar ideas was crucial since White society was hostile and distrustful of the Reds. Evidence of this negative attitude can be found, for example, in a letter that two schoolmistresses and the mistress of a wealthy house sent to the authorities concerning Selma Aronen:

She has always been the first one to sing and rage behind the red cloth and has agitated others to strikes and riots. She has raised her children to be snoopers both in school and in the village. [...] From many years' experience we know that Selma Aronen's secret and public actions are very dangerous to society. 81

The women of the Aronen family continued to have political influence even after the Civil War. And this happened rather soon. Despite the sentences, the social democrats were again the largest party in parliament in 1919. Many of the reforms they had demanded in 1917 were legislated after the war. Thus, the Civil War ended in a compromise. It is quite unique for the losers of a war to be able to gain their demands so soon afterwards. ${ }^{82}$ At the beginning of the 1920 , the labour movement split into social democrats and communists. Three women from the Aronen family formed a new communist association for women in the Pori region and became members of the board. They later became local communist leaders. All the younger women in the family later became communists; only Anna remained a social democrat. ${ }^{83}$

8o Parish Archives of Pori and Ulvila; Juha Kuoppasalmi, Nestori Aronen - tunteita ja taisteluita (Helsinki: self-published, 2018), p. 93.

81 National Archive, Court for crimes against the State (VRYO), doc. 20898.

82 Pertti Haapala, "Yhteiskunnallinen kompromissi", in Haapala and Hoppu, Sisällissodan pikkujättiläinen, pp. 395-404, 404.

83 Lintunen, Punaisten naisten tiet, p. 205. 
This chapter had two main objectives. First, we wanted to empirically study Red women's social relations at different levels. Second, we wanted to test how historical network analysis could be applied as a tool for distant reading in order to quantify and model social networks.

Our analysis shows that the Red women came as closely tied groups from certain quarters of the town. Furthermore, membership of workers' associations and the local trade union branches united women from different neighbourhoods. The trade union memberships prove that the women worked in the same workplaces. They were thus able to meet daily and also to discuss the revolution together and ponder whether to join the Guard or not. Put in more theoretical terms, daily encounters with politically like-minded sisters strengthened emotional closeness, which broadened the connections of these women and provided both information and support, helping them to survive after the war. Our results support the hypothesis that there was a strong social basis for Red activity. Socialist activity in the spring of 1918 in Finland was not only an outcome of ideological manipulation.

Our results support the assumption that membership of a trade union branch or workers' association was an important factor in support for the Red Guard. Previous studies have evidenced this phenomenon with regard to men. Our study indicates a similar tendency among women. There were thus strong similarities between the two genders with regard to the impact of organizational membership.

The application of network analysis helped us to improve our understanding of the social cohesion among these Red women, and of how organizational membership strengthened the geographical connectedness between different districts. Our analysis showed that the most active people lived in different districts and were connected by membership. At the same time, this network analysis helps us to understand why not all women needed to be members of labour organizations in order to gain access to political information.

The network structure underlines the importance of geographical closeness. Since the most active women lived in various districts, they acted as mediators and gatekeepers between the organizations and non-members in their own districts. Another interesting finding is that network components correlate with geographical distance to Pori city centre. Those districts further than walking distance from Pori city centre form isolated localities in our network structure. A closer look at the giant component in our network structure 
reveals that this component brings together women living close together in Pori's city centre.

Our findings also provide support for the relevance of geographical closeness as a factor intensifying social interaction patterns. Although we cannot document how the women included in our material really interacted, or how intense connections between them were, the idea of emotional closeness fostered by geographical and social closeness gains support from the findings of previous studies on kinship and elite networks.

The use of HNA has yielded many interesting and valuable insights into the social structure of Red women in the Pori region on the eve of the Civil War, but the real analytical power lies in combining the quantitative analysis with a qualitative interpretation. On the one hand, the network analysis helped us to identify important women in the network. On the other, through qualitative analysis we were able to reconstruct the historical context and thus explain why these individuals were so important in our networks.

In his critical article on historical network research published in 1998, Charles Wetherell listed three main reasons for the slow adoption by historians of quantitative, computational methods: a lack of familiarity with the conceptual orientation, the fact that the number of quantitatively oriented historians is so few, and the formidable requirements in relation to data in a discipline "plagued with an incomplete historical record and imperfect understandings of past social relations". ${ }^{84}$ This is also partly connected with the so-called cultural turn and microhistorical turn, both of which have diminished the role of quantitatively oriented research. This is alarming, since "the present status of digital history studies shows that the history project benefits from applying digital humanities tools to the study, obtaining new answers to old questions without denying the benefits of digital archives and methods". ${ }^{85}$ Our chapter combines the microhistorical approach with strong computational orientation. Since the method is rather independent of the amount of data used in the analysis, it can help researchers to cope with very much larger datasets

84 Wetherell, "Historical Social Network Analysis", p. 125. A similar assessment can be found, for example, in Raymond L. Garthoff, "Foreign Intelligence and the Historiography of the Cold War", Journal of Cold War Studies, 6:2 (2004), pp. 21-56, Claire Lemercier, Formal Network Methods in History: Why and How?, available at http://halshs.archives-ouvertes. $\mathrm{fr} /$ halshs-00521527/fr; last accessed 4 March 2019, and Christian Rollinger et al., "Editors' Introduction", Journal of Historical Network Research, 1 (2017), pp. i-vii.

85 Qing Wang, "Distribution Features and Intellectual Structures of Digital Humanities: A Bibliometric Analysis", Journal of Documentation, 74:1 (2017), p. 238. 
containing information on social interaction, thus helping us gain new insights into the past.

\section{Bibliography}

Alapuro, Risto, State and Revolution in Finland (Berkeley, CA: University of California Press, 1988).

Alapuro, Risto, Suomen synty paikallisena ilmiönä 1890-1933 (Helsinki: Hanki ja Jää, 1994).

Anttonen, Varpu, "Valkeakosken naiskaarti Suomen sisällissodassa 1918" (Master's thesis, University of Tampere, 2009).

Bearman, Peter, et al., "Networks and History", Complexity 8, no. 1 (2002): 61-71.

Borgatti, Stephen P., and Martin G. Everett, "Network Analysis of 2-Mode Data", Social Networks 19, no. 3 (1997): 243-269.

Brandes, Ulrik, Sven Kosub, and Bobo Nick, "Was messen Zentralitätsindizes?", in Die Integration von Theorie und Methode in der Netzwerkforschung, ed. Marina Hennig and Christian Stegbauer (Wiesbaden: Springer, 2012), 33-52.

Bras, Hilde, and Theo van Tilburg, "Kinship and Social Networks: A Regional Analysis of Sibling Relations in Twentieth-Century Netherlands", Journal of Family History 32 , no. 3 (2007): $296-322$.

Brughmans, Tom, "Thinking Through Networks: A Review of Formal Network Methods in Archaeology", Journal of Archaeological Method and Theory 20, no. 4 (2013): 623-662.

Burdick, Anne et al., ed., Digital_Humanities (Cambridge, MA: MIT Press, 2012).

Burt, Ronald S., "Decay Functions", Social Networks 22 (2000):1-28.

Burt, Ronald S., "Structural Holes versus Network Closure as Social Capital", in Social Capital: Theory and Research, ed. Nan Lin, Karen S. Cook, and Ronald S. Burt (Berlin: De Gruyter, 2001), 31-56.

Clavert, Frédéric, and Serge Noiret, ed., L'histoire contemporaine à lère numérique / Contemporary History in the Digital Age (Brussels: Peter Lang, 2013).

Düring, Marten, and Martin Stark, "Historical Network Analysis", Encyclopedia of Social Networks. Volume 2 (London: Sage, 2011), 593-595.

Enbom, Leena, Työväentalolle vai seurahuoneelle? - Työväen vapaa-ajantoiminta, politiikkaja vastarinta 1920 - ja 19зо-lukujen tehdasyhdyskunnassa (Helsinki:Työväen historian ja perinteen tutkimuksen seura, 2014).

Epple, Ruedi, "Flucht und Unterstützung: Die 'Auskunftsstelle für Flüchtlinge' in Zürich und ihre Netzwerke", Journal of Historical Network Research 1, no. 1 (2017): 106-145.

Garthoff, Raymond L., "Foreign Intelligence and the Historiography of the Cold War", Journal of Cold War Studies 6, no. 2 (2004): 21-56. 
Gold, Matthew K., and Lauren F. Klein, ed., Debates in the Digital Humanities 2016 (Minneapolis, MN: University of Minnesota Press, 2016).

Haapala, Pertti, “Vuoden 1917 kriisi”, in Sisällissodan pikkujättiläinen, ed. Pertti Haapala and Tuomas Hoppu (Helsinki: wsoy, 2009), 58-89.

Haapala, Pertti, "The Expected and Non-Expected Roots of Chaos: Preconditions", in The Finnish Civil War 1918: History, Memory, Legacy, ed. Tuomas Tepora and Aapo Roselius (Leiden: Brill, 2014), 42-50.

Haapala, Pertti, and Marko Tikka, "Revolution, Civil War, and Terror in Finland in 1918", in War in Peace: Paramilitary Violence in Europe after the Great War, ed. Robert Gerwarth and John Horne (Oxford: Oxford University Press, 2012), 72-84.

Hoppu, Tuomas, Tampereen naiskaartit. Myytitja todellisuus (Jyväskylä: Ajatus, 2008).

Hoppu, Tuomas, "Sisällissodan puhkeaminen", in Sisällissodan pikkujättiläinen, ed. Pertti Haapala and Tuomas Hoppu (Helsinki: ws oY, 2009), 92-111.

Hoppu, Tuomas, Sisällissodan naiskaartit. Suomalaisnaiset aseissa 1918 (Helsinki: Gummerus, 2017).

Kalela, Jorma, "Suomi ja eurooppalainen vallankumousvaihe", in Suomalaisen yhteiskunnan poliittinen historia, ed. Ville Pernaa and Mari K. Niemi (Helsinki: Edita, 2008), 95-109.

Klemettilä, Aimo, Tampereen punakaarti ja sen jäsenistö (Tampere: Acta Universitatis Tamperensis, 1976).

Kinnunen, Tiina, "The Post-Cold War Memory Culture of the Civil War: Old-New Patterns and New Approaches", in The Finnish Civil War 1918: History, Memory, Legacy, ed. Tuomas Tepora and Aapo Roselius (Leiden: Brill, 2014), pp. 401-439.

Koivuniemi, Jussi, Joen rytmissä. Porin kaupungin historia 1940-20oo (Pori: Porin kaupunki, 2004).

Kuoppasalmi,Juha,NestoriAronen-tunteitajataisteluita(Helsinki:self-published, 2018). Lintunen, Tiina, Punaisten naisten tiet. Valtiorikosoikeuteen vuonna 1918 joutuneiden Porin seudun naisten toiminta sota-aikana, tuomiot ja myöhemmät elämänvaiheet (Turku: Kustannusosakeyhtiö Otava, 2015).

Morrissey, Robert M., "Archives of Connection", Historical Methods: A Journal of Quantitative and Interdisciplinary History 48, no. 2 (2015): 67-79.

Opsahl, Tore, and Pietro Panzarasa, "Clustering in Weighted Networks", Social Networks 31, no. 2 (2009): 155-163.

Paavolainen, Jaakko, Poliittiset väkivaltaisuudet Suomessa 1918, 2 vols (Helsinki: Tammi, 1966-1967).

Piddington, Ralph, “The Kinship Network among French Canadians”, International Journal of Comparative Sociology, 6 (1965): 145-165.

Prell, Christina, Social Network Analysis: History, Theory and Methodology (London: SAGE, 2012).

Rasila, Viljo, Kansalaissodan sosiaalinen tausta (Helsinki: Tammi, 1968). 
Roberts, Sam G.B., and Robin I.M. Dunbar, "Communication in Social Networks: Effects of Kinship, Network Size, and Emotional Closeness”, Personal Relationships, 18 (2011): 439-452.

Rollinger, Christian, et al., "Editors' Introduction", Journal of Historical Network Research 1 (2017): i-vii.

Rosenberg, William G., "Paramilitary Violence in Russia's Civil Wars, 1918-1920", in War in Peace: Paramilitary Violence in Europe after the Great War, ed. Robert Gerwarth and John Horne (Oxford: Oxford University Press, 2012), 21-39.

Salkola, Marja-Leena, Työväenkaartien synty ja kehitys punakaarteiksi 2 (Helsinki: Valtion painatuskeskus, 1985).

Schultz-Jones, Barbara, "Examining Information Behavior Through Social Networks: An Interdisciplinary Review”, Journal of Documentation 65, no. 4 (2009): 592-631.

Scott, John, Social Network Analysis (London: SAG E, 2013).

Smith, R.M., "Kin and Neighbors in a Thirteenth-Century Suffolk Community", Journal of Family History 4, no. 3 (1979): 219-256.

Tepora, Tuomas, and Aapo Roselius, "Introduction: The Finnish Civil War, Revolution and Scholarship", in The Finnish Civil War 1918: History, Memory, Legacy, ed. Tuomas Tepora and Aapo Roselius (Leiden: Brill, 2014), 1-19.

Teräs, Kari, Arjessa ja liikkeessä. Verkostonäkökulma modernisoituviin työelämän suhteisiin 1880-1920 (Helsinki: Suomalaisen Kirjallisuuden Seura, 2001).

Tikka, Marko, "Warfare and Terror in 1918", in The Finnish Civil War 1918: History, Memory, Legacy, ed. Tuomas Tepora and Aapo Roselius (Leiden: Brill, 2014): 90-118.

Tikka, Marko, "Suomen sisällissodan tapahtumat", in Rikki revitty maa, ed. Tuomas Tepora and Aapo Roselius (Helsinki: Gaudeamus, 2018): 82-110.

Upton, Anthony F., The Finnish Revolution, 1917-1918 (Minneapolis, MN: University of Minnesota Press, 1980).

Wang, Qing, "Distribution Features and Intellectual Structures of Digital Humanities: A Bibliometric Analysis", Journal of Documentation 74, no. 1 (2017): 223-246.

Wellman, Barry, and Charles Wetherell, "Social Network Analysis of Historical Communities: Some Questions from the Present for the Past", The History of the Family 1, no. 1 (1996): 97-121.

Wetherell, Charles, "Historical Social Network Analysis", International Review of Social History 43:S6 (1998): 125-144.

Yin, Ling, and Shih-Lung Shaw, "Exploring Space - Time Paths in Physical and Social Closeness Spaces: A Space - Time GIS Approach", International Journal of Geographical Information Science 29, no. 5 (2015): 742-761.

Ylikangas, Heikki, Tie Tampereelle. Dokumentoitu kuvaus Tampereen antautumiseen johtaneista sotatapahtumista Suomen sisällissodassa 1918 (Porvoo: W. Söderström, 1996). Ylitalo, Essi, “'Innokas punikki'. Hyvinkään punakaartilaisnaiset sisällissodan jälkiselvittelyissä 1918” (Master's thesis, University of Helsinki, 2011). 